\title{
Robert Conrad
}

\section{The \\ Destruction of \\ Brazilian Slavery \\ 1850-1888}


SOURCES OF THE ILLUSTRATIONS

Frontispiece: Richard F. Burton, Explorations of the Highlands of the Brazil (London, 1869), Vol. I; numbers 1 through 12: J. B. Debret, Voyage Pittoresque et historique au Brésil (3 vols., Paris, 1834, 1835, 1839); number 13: Charles Edmond Akers, A History of South America (E. P. Dutton \& Co., New York, 1904); number 14: William Hadfield, Brazil and the River Plate (London, 1877); numbers 15, 16, and 25: Biblioteca Nacional, Rio de Janeiro; numbers 17 through 19, 22, and 24: Arquivo do Museu Imperial, Petrópolis; number 20: André Rebouças, Diário e notas autobiográficas (Livraria José Olympio Editôra, Rio de Janeiro, 1938); number 21 : Revista lllustrada (1884); number 23: Brazil. Ministerio da Educação, Floriano, Memórias e Documentos (Rio de Janeiro, 1939), Vol. II; number 26: Reginald Lloyd, ed., Twentieth Century Impressions of Brazil (London, 1913).

University of California Press

Berkeley and Los Angeles, California

University of California Press, Ltd.

London, England

Copyright (C) 1972, by

The Regents of the University of California

ISBN 0-520-02139-8 (Cloth) 0-520-02371-4 (Paper)

Library of Congress Catalog Card Number: 74-174457

Printed in the United States of America

Designed by W. H. Snyder 


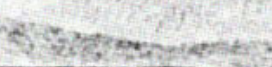

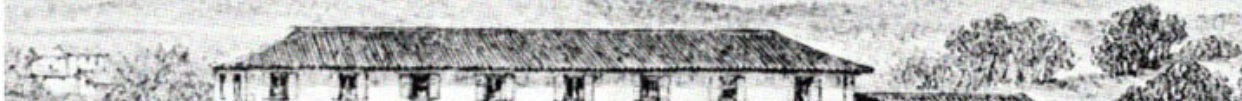

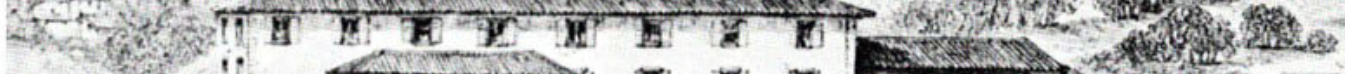

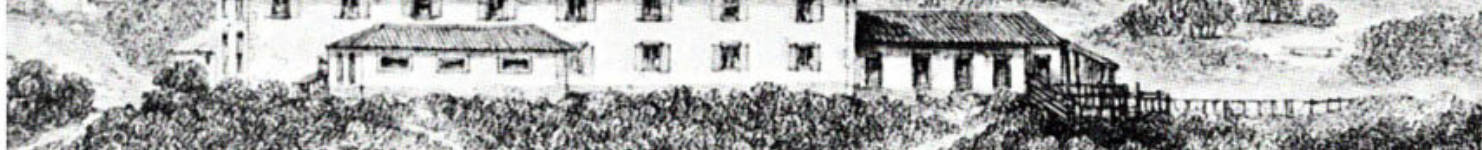

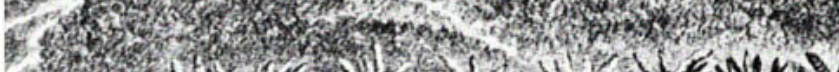

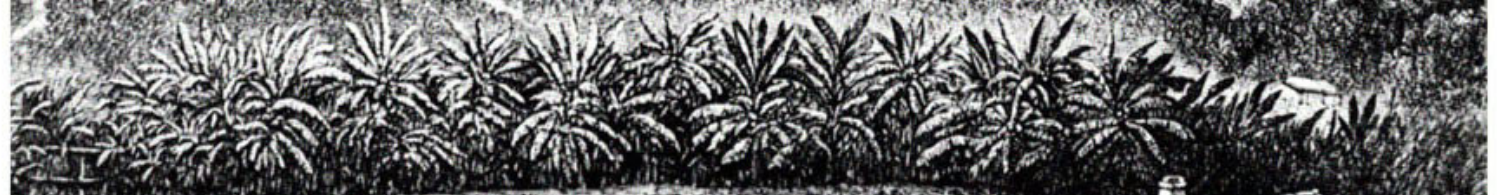

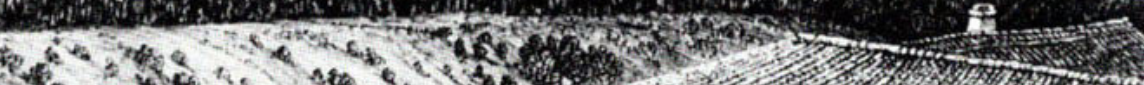

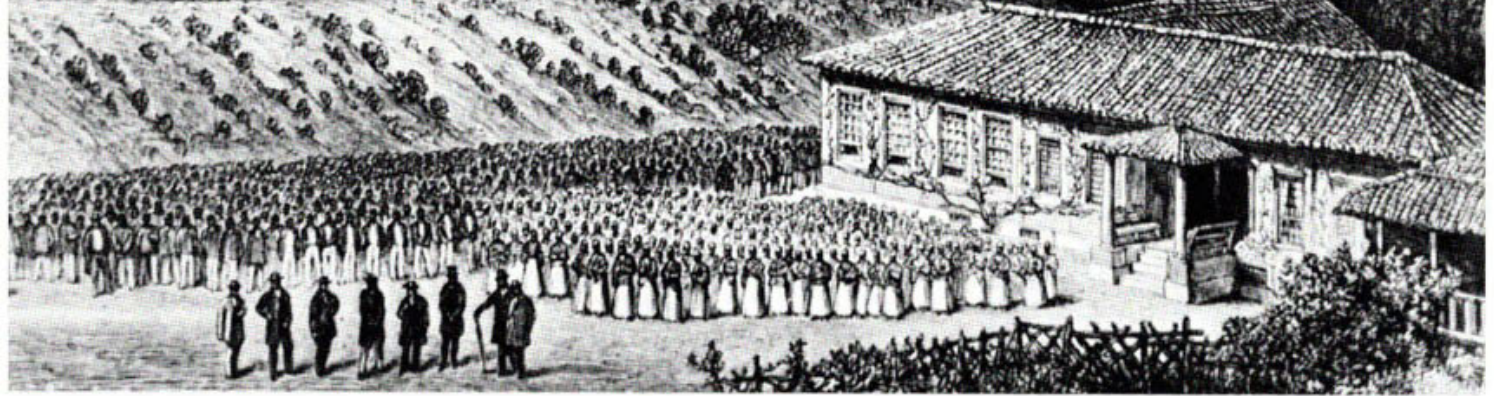

"The Fortnightly Slave-Muster at the Casa Grande, Morro Velho" 
THE DESTRUCTION OF BRAZILIAN SLAVERY

1850-1888 

To Ursula 